\title{
Efficacy of bio and synthetic pesticides against the American bollworm and their natural enemies on cotton
}

\author{
D. Gayi ${ }^{1}$, D. Ocen ${ }^{1}$, G. Lubadde ${ }^{1}$ and L. Serunjogi ${ }^{2}$ \\ ${ }^{1}$ National Semi-Arid Resources Research Institute (NaSARRI), Uganda \\ ${ }^{2}$ Cotton Development organization (CDO), Uganda \\ Author for correspondence: gayidennis1983@gmail.com
}

\begin{abstract}
Cotton production in Uganda is limited by various factors among which insects pests are the most important. The key insect pests of cotton are the bollworm complex; spotted bollworm, Earias insulana; pink bollworm, Pectinophora gossypiella and American bollworm, Helicoverpa armigera. The American bollworm is an alien species and the most disastrous among all the three bollworm species attacking cotton in Uganda. Management for the bollworm complex in Uganda is largely synthetic chemical use with little or no biopesticide use which reduces natural enemies population and resistance development to continuous use of a single synthetic pesticide product. Therefore this study aimed at determining the efficacy of bio and synthetic pesticides on the management of cotton bollworm pests with special reference to the American bollworm. The pesticides in the study included Nimbecidine (Azaradactin), Engeo K247SC (Lambda Cyhalothrin 106 g l$^{-1}+$ Thiamethoxam $141 \mathrm{~g} \mathrm{l}^{-1}$ ), Talstar (Bifenthrin), and Amdoc3EC (Emamectin and Abamectin), Aster extreme 20SL (Acetamiprid 150g/l and Cypermethrin $\left.50 \mathrm{~g} \mathrm{l}^{-1}\right)$, Agrolambacin $\left(15 \mathrm{~g} \mathrm{l}^{-1} \mathrm{Lambda}\right.$ Cyhalothrin + $300 \mathrm{~g} \mathrm{l}^{-1}$ Profenofos), Thiodicarb (Larvin 80DF), and Methomyl (Lannate 40SP) on cotton bollworm (Helicoverpa amigera) and its natural enemies in eastern Uganda. The study was conducted at the National Semi-Arid Resources Research Institute (NaSARRI) under both laboratory and field conditions. Under laboratory controlled conditions, recommended doses of these bio and synthetic pesticides were used against third instar larvae of the American bollworm in a completely randomised experimental design with five replicates. Amdoc 3EC and Nimbecidine, showed maximum efficacy, $100 \%$, in terms of mortality after 72 hours. While Engeo, Aster extreme and Agrolambacin showed maximum mortality of (100\%) after 96 hours followed by Larvin 80DF (80\%) and Lannate 40SP $(67 \%)$. In the field conditions, Nimbecidine (0.3 and 1.00) and Talstar (2.0 and 1.7) were the most effective bio-pesticides; while Amdoc with means (1.8 and 1.9), Aster extreme (2.0 and 1.8) and Agrolambacin (1.5 and 1.3) were the most effective synthetic pesticides respectively. Seed cotton yield was significantly higher in biopesticide treated plots, Talstar $1966,1935 \mathrm{~kg} \mathrm{ha}^{-1}$, Nimbicidine 1985 and $1715 \mathrm{~kg} \mathrm{ha}^{-1}$ compared to the synthetic pesticide treated plots with amdoc1935 and 1506 , Agrolambacin 1846 and $1722 \mathrm{~kg} \mathrm{ha}^{-1}$, Aster extreme 1733 and $1930 \mathrm{~kg} \mathrm{ha}^{-1}$ respectively. Computation of the benefit cost ratios showed that these new chemical pesticides were all financially viable and, therefore, adoptable by the cotton farmers, respectively which also performed better than the controls 1012 and $912 \mathrm{~kg} \mathrm{ha}^{-1}$ outside the experiment, 892 and $602 \mathrm{~kg} \mathrm{ha}^{-1}$ inside the experimental area. In addition, synthetic pesticides
\end{abstract}


treated plots were associated with significant reductions in natural enemies populations. In contrast biopesticide treatments had minimum side effects on the natural enemies populations.

Key words: Cotton, Helicoverpa amigera

\section{Introduction}

Cotton, Gossypium hirsutum L. (Family Malvaceae), is the most commercially important among fiber perennial semishrub crops in the world (Naveed et al., 2015). In Uganda, it is the fourth largest traditional export cash crop after coffee, tea and tobacco (UBOS, 2015). It is mainly grown as a fibre crop for the textile industry, but its seeds provides hulls, oil and animal feed (Syed et al., 2015). Cotton productivity in Uganda is $500 \mathrm{~kg}$ $\mathrm{ha}^{-1}$, which is considerably less than in countries such as China with $1580 \mathrm{~kg}$ $\mathrm{ha}^{-1}$ (USDA, 2016). The growth in cotton production in Uganda has been primarily due to expansion of area planted than improvement in yield per unit area planted (CDO, 2013).

The major constraints to cotton production in Uganda are pests and diseases, which reduce pre- and postharvest quality and quantity of both lint and seed cotton (Waturu et al., 2002). Among these pests, the American bollworm, Helicoverpa armigera "Hub", is the most destructive, with significant yield losses ranging from $30-100 \%$ if not controlled (CABI, 2016). The main management measure for its control is the application of synthetic pesticides and miticides, which accounts for $57 \%$ of all cotton production costs (Ngari et al., 2007). Extensive use of insecticides with single mode of action, or group may lead to occurrence of resistance especially for H. armigera (Yongqiang Li et al., 2016).
High levels of resistance to conventional insecticides in $H$. armigera and other pests of cotton has been reported (Surpam et al., 2015). In order to reduce chances of insecticide resistance to the synthetic insecticide in use, continuous evaluation of new insecticides would be necessary, and as a result there would be enough insecticides for rotating in an attempt to manage pest resistance.

Rotation of insecticides is one strategy for managing insect resistance (Roush and Luthrel, 1989). The other way of reducing the chances of resistance development is the use of insecticide mixtures, where Nimbecidine (Azaradactin), Engeo K247SC (Lambda Cyhalothrin 106g l-1 + Thiamethoxam 141 $\mathrm{g} \mathrm{l}^{-1}$ ), Talstar (Bifenthrin), and Amdoc3EC (Emamectin and Abamectin), Aster extreme 20SL (Acetamiprid $150 \mathrm{~g} \mathrm{l}^{-1}$ and Cypermethrin 50 $\mathrm{g} \mathrm{l}^{-1}$ ), Agrolambacin $\left(15 \mathrm{~g} \mathrm{l}^{-1}\right.$ Lambda Cyhalothrin $+300 \mathrm{~g} \mathrm{l}^{-1}$ Profenofos), Thiodicarb (Larvin 80DF), and Methomyl (Lannate 40SP), a combination of two active ingredients would be suitable. More still, with these new chemistries, it is of benefit to a farmer to understand the financial viability of the new technologies on the market, in order to make profitable decisions. Therefore, this study was conducted to evaluate the efficacy of new chemistry insecticides against the American bollworm and their natural enemies under controlled laboratory and field conditions; and compare the cost benefit analysis of these new chemistries on the seed cotton yield. 


\section{Material and methods}

Larvae of the American bollworm were reared on cotton squares and bolls at the National Semi Arid Resources Research Institute(NaSARRI) in the laboratory at $28 \pm 2{ }^{\circ} \mathrm{C}$ and $65 \pm 2 \%$ relative humidity, with a photoperiod of 16:8 (Light: Dark) hr. Third instar larvae of the American bollworms were treated with Nimbecidine (Azaradactin), Engeo K247SC (Lambda Cyhalothrin 106 $\mathrm{g} \mathrm{l}^{-1}+$ Thiamethoxam 141 $\mathrm{g}^{-1}$ ), Talstar (Bifenthrin), and Amdoc3EC (Emamectin and Abamectin), Aster extreme 20SL (Acetamiprid $150 \mathrm{~g}^{-1}$ and Cypermethrin $50 \mathrm{~g} \mathrm{l}^{-1}$ ), Agrolambacin (15 $\mathrm{g} \mathrm{l}^{-1}$ Lambda Cyhalothrin $+300 \mathrm{~g} \mathrm{l}^{-1}$ Profenofos), Thiodicarb (Larvin 80DF), and Methomyl (Lannate 40SP), using a leaf dip method (Busvine, 1971). The Formulations of test solutions were prepared by dissolving the chemicals in distilled water as parts per million of active in-gradients (100 ppm).

Cotton leaf disks ( $5 \mathrm{~cm}$ diameter) were cut and dipped into the test solutions for 15 seconds with gentle agitation. They were allowed to surface-dry on a paper towel and were then placed into petridishes containing moistened filter papers, to avoid desiccation of the leaves. Third instar larvae were transferred to the leaf disks, by tapping lightly to dispense 5 larvae per petri-dish per replicate. Each treatment was replicated 5 times a long with an untreated control, under completely randomised design (CRD). Mortality was assessed after 24, 48 and 72 and 96 hours, after introducing the third instars to insecticide treated leaf disks. The larvae were considered dead if they gave no response to stimulation by touch. Results were expressed as percentage mortality, with correction for untreated (control) mortality using Abbott's formula (Abbott, 1925) ie;

1. The difference between the percentage of living American bollworm in the untreated check and the percentage of living American bollworm in the treated plot gives the percentage of the original number actually killed by the treatment.

2. When a certain number of the American bollworms, as for example 20 percent, is found to have died from natural causes, it logically follows that only 80 percent- of the original infestation was living and could have been killed by the treatment applied.

3. Since only 80 per cent of the American bollworm could have been killed by the spray the, per cent control" would be determined by comparing the number actually killed with the number of living American bollworm in the check. This may be reduced to a simple formula as follows:

Let $\mathrm{X}$ : the per cent living American bollworm larvae in the check. equation 1

Let Y: the per cent American bollworm larvae living in the treated plot. equation 2

Then X - Y: is the per cent American bollworm larvae killed by the treatment.

And the percent American bollworm larvae killed by the treatment $(\mathrm{X}-\mathrm{Y})$ divided by the per cent American bollworm larvae living in the check (X) gives the control or expressed by, an equation, X_Y/ X x 100 = per cent control)........................ equation 3 
For the field experiments, cotton variety BPA 2002 seeds were delinted using concentrated sulphuric acid (Costelloe, 1968; Munro, 1987) and dressed with Cruiser extra (Thiamethoxam) at $3 \mathrm{ml}$ $\mathrm{kg}^{-1}$ of seed. Three to four cotton seeds were planted per hole at inter- and intrarow spacings of $100 \mathrm{~cm}$ and $30 \mathrm{~cm}$, respectively, during the first week of August 2013 and April 2014.

Plots were measuring 5 x 5 metres were separated with a path of 2 metres between plots and blocks arranged in a randomised complete block design (RCBD), with 3 replications.

Agronomic practices including gap filling, thinning, weeding were carried out manually as recommended (Waturu et al., 2002). The experimental fields remained unsprayed from planting up to two weeks after first squaring, to allow for establishment and development of the cotton bollworm pest. The Helicoverpa amigera populations were monitored twice a week; and spraying only started when the bollworm population reached at/ or above economic threshold level (ETL) of 5 larvae per 15 plants examined.

The treatments included; Amdoc EC $300 \mathrm{ml} \mathrm{ha}^{-1}$, this pesticide is a double sword pesticide with both an insecticide and acaricidal activities, its non-systemic with both contact and stomach actions, targeting mainly mites, Heliothis spp and thrips.

Engeo $300 \mathrm{ml} \mathrm{ha}^{-1,}$ this is aneonicotiriod pyrethroid with both systemic and contact activity mainly for aphids, whiteflies and chewing insects.

Aster extreme $250 \mathrm{ml} \mathrm{h}$, this is both a contact and systemic pesticide with Translaminar activity effective on aphids, leafminer, white flies and all chewing insects including bollworms.
Agrolambacin $300 \mathrm{ml} \mathrm{ha}^{-1}$, this has both contact and stomach actions. Nimbicidine $300 \mathrm{ml} \mathrm{ha}^{-1}$ (this is a biopesticide with insect growth regulator, feeding deterent, sterilant, insecticidal and oviposition deterent. its target pests include Orthoptera, Coleoptera, hethoptera, Homoptera, Diptera and Lepidoptera .Larvin $400 \mathrm{~g}$, this is a carbamate effective on chewing pests of cotton, it is an acetyl cholinesterase inhibitor white powder.

Talstar $300 \mathrm{ml} \mathrm{ha}^{-1}$, it is a pyrethroid with both contact and stomach actions recommended for Orthoptera, Coleoptera, Homoptera, Diptera and Lepidoptera, Lannate $500 \mathrm{gm}$, it is an acetyl cholinesterase inhibitor recommended mainly for bollworms and semi loopers, it has both insecticidal and acaricide properties.

And two untreated controls, one within the treated and an outside control five metres away from the sprayed area. Where the control is surrounded by three or four sides, the dispersal of insects, into and out of control, were restricted by the sprayed cotton. This might lead to heavier or lighter pest attack in the control plots than would occur in the isolated unsprayed plots.

Cost benefit analysis (CBA) cost ration of these new chemicals in this study, were calculated as the benefit cost ratio shown by the equation below.

\section{$\mathrm{BCR}=\underline{\text { Program benefits }}$ Program costs}

Where:

1. Program benefits denotes benefits or revenue in the season or year, and in this study was the income from sale of seed cotton 
2. Program costs denotes all the costs incurred to produce the benefits in the season or year which were the costs incurred in production of seed cotton in each respective season

The decision rule for BCR is that if:

$\mathrm{BCR}>1$ then it means that the seed cotton produced under this technology is financially viable.

$\mathrm{BCR}<1$ then it means that the seed cotton produced under that method is not financially viable

$\mathrm{BCR}=1$ means that there is a breakeven.

\section{Data collection and analysis}

For the controlled laboratory experiment, data were collected on number of bollworm larvae killed by each treatment 24, 48, 72 and $96 \mathrm{hr}$ after application and expressed as percentage mortality. For the field experiment, data were collected twice, once at squaring and once at boll growth 5, 10 and 15 days after spraying, since the highest pesticide activity is known to occur in the first 15 days after spraying (Muhammad et al., 2004). Spraying was carried out twice, 20 days after spraying from two weeks, when first squares were observed. Averages of live bollworm larvae per 5 leaves randomly sampled, natural enemies counts and seed cotton yields were also collected.

$$
\mathrm{BCR}=\frac{\text { Program benefits }}{\text { Program costs }}
$$

Was used to determine the financial viability of each of the new pesticides in this study. The data on live natural enemies counts, damaged squares and mean yield per hectare were subjected to ANOVA and means separated using LSD.

\section{Results}

\section{Efficacy under control laboratory condition}

Table 1 shows that percent mortality of the $3^{\text {rd }}$ instar larvae of the American bollworm, $H$. armigera varied significantly $(\mathrm{p}<0.05)$ among the treatments and control. The mortality varied among periods of 24, 48, 72 and 96 hours. After $24 \mathrm{hr}$, the maximum mortality was observed in Amdoc 3EC (65\%) and Lannet, with at least 50\% knockdown and the least $(15 \%)$ mortality was recorded in Talstar. After $48 \mathrm{hr}$, Amdoc 3EC gave the highest mortality (80\%), followed by Aster extreme $(75 \%)$, Nimbecidine $(70 \%)$ and $25 \%$ mortality for Talstar. Amdoc 3EC and Nimbicidine gave $100 \%$ mortality, followed by Agrolambacin (87\%), Aster extreme (85\%) and Engeo (80\%) after $72 \mathrm{hr}$. Results at $96 \mathrm{hr}$ showed that the maximum percent mortality (100\%) of the $3^{\text {rd }}$ instar larvae of the African bollworm was recorded in Engeo, Agrolambacin and Aster extreme 20SL, followed by Larvin (80\%), Talstar (78\%) and Lannet (67\%). The maximum mean percent mortality was recorded in Agrolambacin (75.5\%), followed by Engeo (67.5\%), Aster extreme (65\%), Amdoc (61.5\%), Larvin(50\%), Nimbicidine (47\%), Talstar (44\%), Lannet (42.8\%) and no mortality was observed in the control treatment 24 , 48,72 and 96 hours post application.

\section{Efficacy under natural field condition}

The results for the two controls were pooled and graphical presented as one control, giving relatively higher occurrences of the pest than the treatment 


\begin{tabular}{|c|c|c|c|c|c|c|}
\hline \multirow[t]{2}{*}{ Biopesticides } & \multirow[t]{2}{*}{$\begin{array}{l}\text { Recommended } \\
\text { rate (Dosage ha') }\end{array}$} & \multirow[t]{2}{*}{$\begin{array}{l}\text { Used } \\
\text { concentration } \\
(\mathrm{ppm})\end{array}$} & \multicolumn{4}{|c|}{$\begin{array}{l}\% \text { mortality of } 3 \text { rd instar Larvae } \\
\text { of Helicoverpa amigera in hours } \\
\text { after introducing larvae in insecticide } \\
\text { treated leaf disks }\end{array}$} \\
\hline & & & $24 \mathrm{hrs}$ & $48 \mathrm{hrs}$ & $72 \mathrm{hrs}$ & $96 \mathrm{hrs}$ \\
\hline Nimbecidine (Azadirachtin) & $1.25 \mathrm{~L}$ & 100 & $18 \mathrm{~d}$ & $70 \mathrm{~b}$ & $100 \mathrm{a}$ & $100 \mathrm{a}$ \\
\hline Engeo K247SC (Lambda Cyhalothrin $106 \mathrm{~g} \mathrm{l}^{-1}$ + Thiamethoxam $141 \mathrm{~g} \mathrm{l}^{-1}$ ) & $0.75 \mathrm{~L}$ & 100 & $25 \mathrm{c}$ & $65 \mathrm{c}$ & $80 \mathrm{~b}$ & $100 \mathrm{a}$ \\
\hline Talstar (Bifenthrin) & $1.25 \mathrm{~L}$ & 100 & $15 \mathrm{~d}$ & $25 \mathrm{~d}$ & $58 \mathrm{c}$ & $78 b$ \\
\hline Amdoc3EC (Abamectin and Emamectin) & $0.2-0.3 \mathrm{~L}$ & 100 & $65 \mathrm{c}$ & $80 \mathrm{~b}$ & $100 \mathrm{a}$ & $100 \mathrm{a}$ \\
\hline Asterextreme20SL (Acetamiprid $150 \mathrm{~g} \mathrm{l}^{-1}$ and Cypermethrin $50 \mathrm{~g} \mathrm{l}^{-1}$ ) & $0.25-0.3 \mathrm{~L}$ & 100 & $45 \mathrm{c}$ & $75 \mathrm{~b}$ & $85 \mathrm{a}$ & $100 \mathrm{a}$ \\
\hline Agrolambacin( $15 \mathrm{~g} \mathrm{l}^{-1}$ Lambda Cyhalothrin $+300 \mathrm{~g} \mathrm{l}^{-1}$ Profenofos $)$ & $1.2 \mathrm{~L}$ & 100 & $50 \mathrm{a}$ & $65 \mathrm{c}$ & $87 \mathrm{a}$ & $100 \mathrm{a}$ \\
\hline Larvin 80DF (Thiodicarb) & $1 \mathrm{~kg}$ & 100 & $16 \mathrm{~d}$ & $48 \mathrm{c}$ & $56 \mathrm{c}$ & $80 \mathrm{~b}$ \\
\hline Lannet 40SP (Methomyl) & $1.25 \mathrm{~kg}$ & 100 & Od & $50 \mathrm{c}$ & $54 \mathrm{c}$ & $67 b$ \\
\hline Control & 0 & 0 & $0 \mathrm{~d}$ & Od & $0 \mathrm{~d}$ & $0 \mathrm{~d}$ \\
\hline
\end{tabular}

Means within columns and rows with same letter(s) are not significantly different from each other at 5\% level of probability (0.05). 
plots, before application of the treatments. and Aster significantly reducing bollworm In the treated plots, maximum mortality larvae 5DAS, 10DAS and 15DAS after was observed in biopesticides, Nimbicidine spraying (Figs. 1 and 2). Unlike in 2014, and Talstar, and synthetic pesticides, Larvin 80DF and Lannet 40Sp showed Agrolambacin, EngeoK247SC, Amdoc very low larval mortalities (Figs.1 and 2).

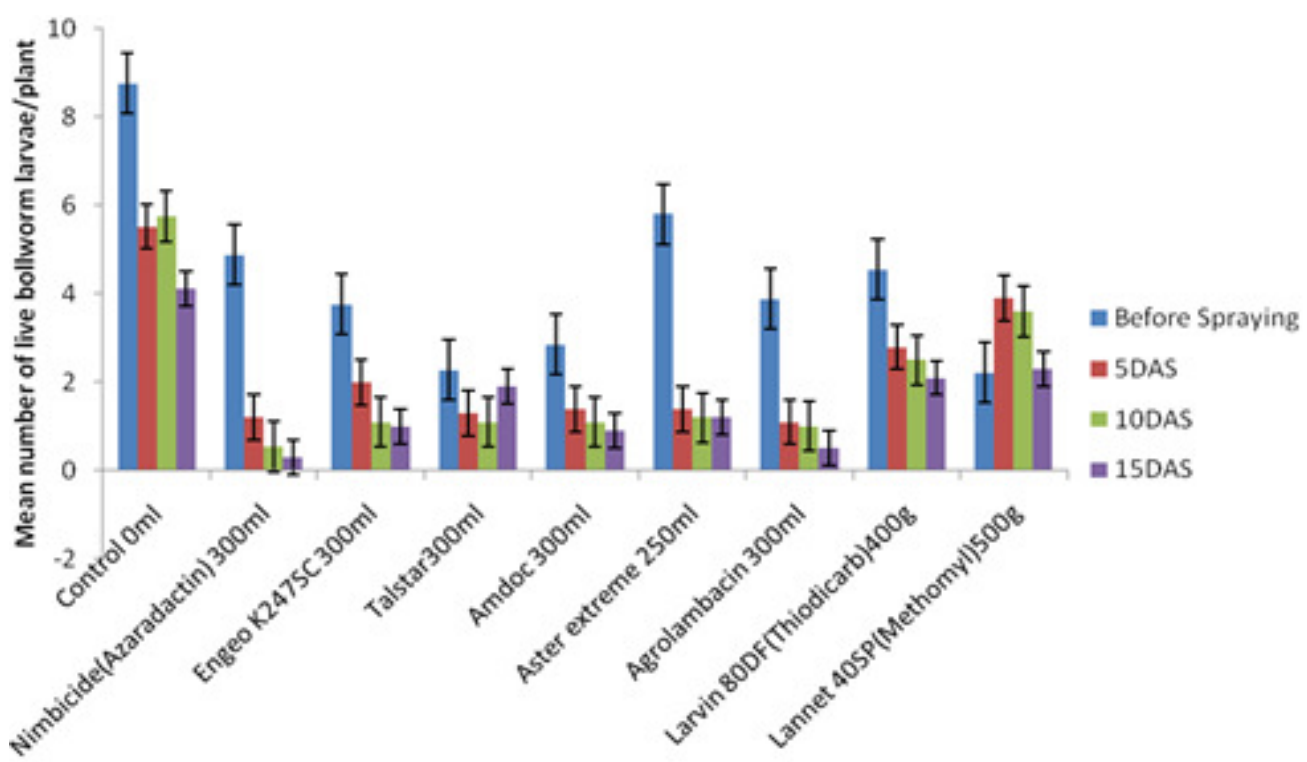

Figure 1. Efficacy of bio and synthetic pesticides against the American bollworm in the field at the National Semi Arid Resources Research Institute in Uganda, DAS = Days after spraying.

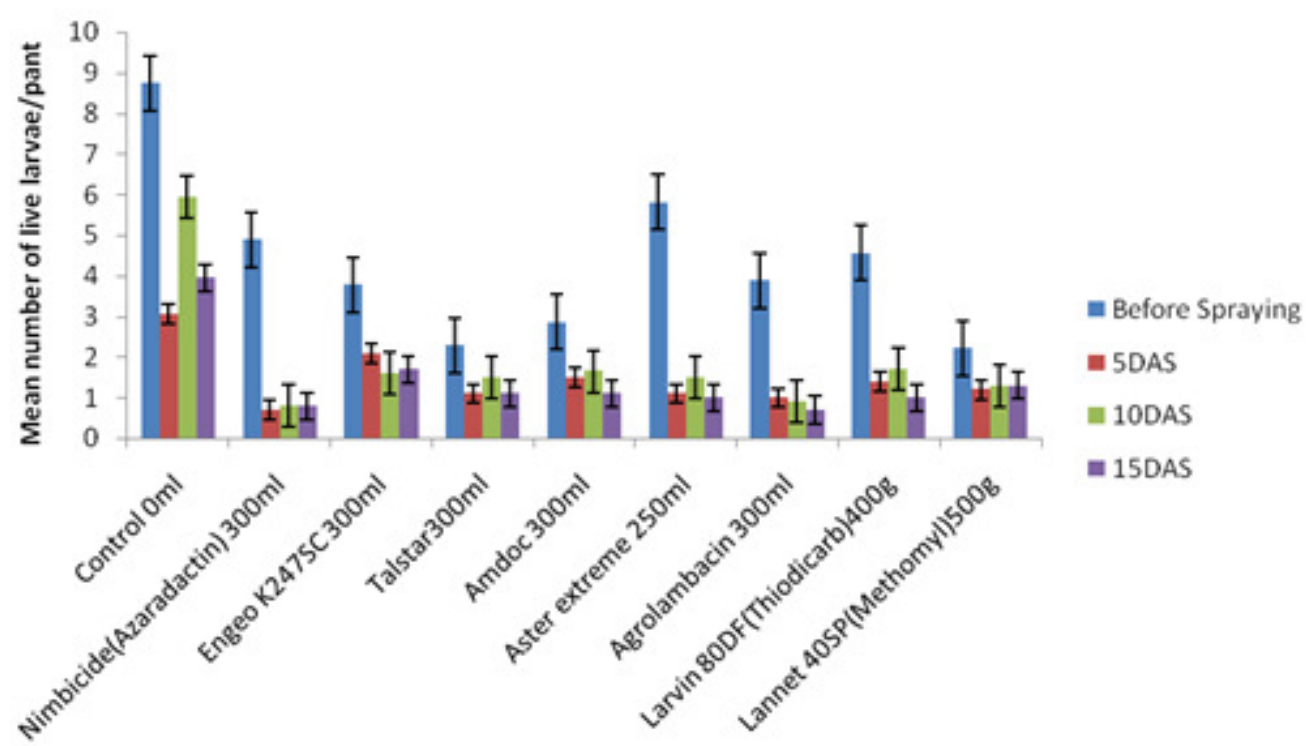

Figure 2. Efficacy of bio and synthetic pesticides against the American bollworm in the field at the National Semi Arid Resources Research Institute, DAS = Days after spraying. 
Similarly, 2014 season showed higher bollworm mortalities with regards to biopesticides. However, the mortality rate for synthetic pesticides followed the same trend as biopesticides 5, 10, 15 days after spraying (Fig. 2).

\section{Effect on natural enemy population}

Mean counts of natural enemies (ladybirds, black ants and Syphidae larvae) are shown in Table 2. All insecticide treatments had significant differences $(p<0.001)$ on mean counts of ladybirds, black ants and Syphidae larvae. Significantly higher survival values were obtained for Nimbicide, Agrolambacin, Amdoc, EngeoK247Sc and Talstar treatments (Table 2). While Aster extreme, Larvin and Lannet showed significant reductions in the mean counts of natural enemies compared to the biopesticides and other pesticides and the two controls (Table 2). The control outside the plots had significantly higher natural enemy counts compared to the control inside the experimental area.
Number of damaged squares, bolls per plant and yields

The numbers of bolls per plant were significantly higher in pesticides treated plots compared with the controls (Tables 3 and 4). Yield results for the three harvest presented as $\mathrm{kg} \mathrm{ha}^{-1}$ had significant differences compared with the controls. The yields were significantly $(\mathrm{p}<0.05)$ higher in pesticide treated plots with less number of damaged bolls compared to the controls with significantly higher number of damaged bolls. Significantly higher yield values were observed in the biopesticides treated plots compared with the synthetic pesticide treated plots and the controls.

Cost benefit analysis of the new chemical pesticides on seed cotton yield production at the National Semi Arid Resources Research Institute (NaSARRI)

The cost benefit analysis (BCR) performed for the new pesticides in this study indicated ratios of 1.3 for

Table 2. Counts of live natural enemies per treatment

\begin{tabular}{lcccc}
\hline & Lady bird & Chysoperla Carnea & Black ants \\
\hline Control inside (No spray) & 9.9 & 1.9 & 9 \\
Amdoc Sc & $300 \mathrm{ml}$ & 3.4 & 1.5 & 3.5 \\
EngeoK247 Sc $300 \mathrm{ml}$ & 4.9 & 0.9 & 1.2 \\
Aster Extreme & $250 \mathrm{ml}$ & 2.1 & 0.5 & 1. \\
Agrolambacin & $300 \mathrm{ml}$ & 5.7 & 2 & 1.5 \\
Nimbicide & $300 \mathrm{ml}$ & 6.2 & 2 & 1.5 \\
Lavin80DF & $400 \mathrm{~g}$ & 1 & 1.3 & 3.2 \\
Talstar & $300 \mathrm{ml}$ & 4.1 & 0 & 1.9 \\
Lannet40SP & $500 \mathrm{ml}$ & 0.8 & 0 & 1.3 \\
Control outside (no spray) & 10.5 & 13.5 & 10.6 \\
& & & & 0.003 \\
P value & $<.001$ & $<0.001$ & 0.48 \\
LSD & 0.16 & 0.98 & \\
\hline
\end{tabular}


Table 3. Counts of damaged squares, boll counts and seed cotton yield at the National Semi Arid Resources Research Institute (NaSARRI), in Uganda

\begin{tabular}{lcccc}
\hline Treatment & $\begin{array}{c}\text { Rate } \\
\left(\text { Dosage } \mathrm{ha}^{-1}\right)\end{array}$ & Dam/Squares & Boll counts & $\begin{array}{c}\text { Mean yield } \\
\left(\mathrm{kg} \mathrm{ha}^{-1}\right)\end{array}$ \\
\hline Control inside & & 5.27 & 40.7 & 892 \\
Amdoc Sc & 300 & 2.25 & 72.5 & 1958 \\
Nimbicide & 300 & 0.15 & 71.2 & 1985 \\
EngeoK247Sc & 300 & 2.23 & 56.7 & 1035 \\
Talstar & 300 & 1.91 & 64.7 & 1966 \\
Aster extreme & 300 & 1.17 & 66.2 & 1733 \\
Agrolambacin & 300 & 1.21 & 84.6 & 1846 \\
Larvin80DF & $400 \mathrm{~g}$ & 2.51 & 51.4 & 1567 \\
Lannet40SP & $500 \mathrm{~g}$ & 5.62 & 55.6 & 1386 \\
Control outside & & 4.04 & 45.0 & 1012 \\
& & & & 5.47 \\
LSD $(0.05)$ & 2.54 & 1.96 & \\
\end{tabular}

Table 4. Counts of damaged squares, boll counts and seed cotton yield at the National Semi Arid Resources Research Institute (NaSARRI) in Uganda

\begin{tabular}{lcccc}
\hline Treatment & $\begin{array}{c}\text { Rate } \\
\left(\text { Dosage ha }{ }^{-1}\right)\end{array}$ & Dam/Squares & Boll counts & $\begin{array}{c}\text { Mean yield } \\
\left(\mathrm{kg} \mathrm{ha}^{-1}\right)\end{array}$ \\
\hline Control inside & & 3.27 & 35.7 & 602 \\
Amdoc Sc & 300 & 2.21 & 72.5 & 1506 \\
Nimbicide & 300 & 1.5 & 71.2 & 1715 \\
EngeoK247Sc & 300 & 2.23 & 56.7 & 1005 \\
Talstar & 300 & 1.91 & 64.7 & 1935 \\
Aster extreme & 300 & 2.17 & 66.2 & 1930 \\
Agrolambacin & 300 & 2.21 & 84.6 & 1722 \\
Larvin80DF & $400 \mathrm{~g}$ & 2.51 & 50.4 & 1360 \\
Lannet40SP & $500 \mathrm{~g}$ & 3.00 & 35.6 & 1080 \\
Control outside & & 3.01 & 40.0 & 912 \\
LSD $(0.05)$ & & & & \\
\hline
\end{tabular}

lannette, 1.6 Larvin, 1.8 Aster extreme, 2.0 Agrolambacin, 2.3 Talstar, 2.3 Amdoc2.4 Nimbicidine compared to 0.6 and 0.8 with no control in 2013 season (Table 5).

Similarly 2014 season showed BCR ratios of 1.9 Lannette, 1.9 EngeoSc, 2.8 Larvin, 3.3 AmdocEC, 3.7 Agrolambacin,
3.9 Nimbicidine, 4.2 Aster extreme and 4.5 Talstar in 2014 season ( Table 6).

The overall implication was that use of these new pesticide products under evaluation in this study was financially viable and can be adopted by farmers since each chemical had a BCR greater 
Table 5. Estimates of cost benefit analysis of the new pesticides in the study at the National Semi Arid Resources Research Institute (NaSARRI) in ${ }^{\prime}$ Uganda

\begin{tabular}{|c|c|c|c|c|c|c|c|c|c|}
\hline Treatments & $\begin{array}{l}\text { Quantity } \\
\text { per ha }\end{array}$ & $\begin{array}{l}\text { Cost per } \\
\text { treatment } \\
\left(\mathrm{US} \$ \mathrm{ha}^{-1}\right)\end{array}$ & $\begin{array}{l}\text { Other } \\
\text { production } \\
\text { costs } \\
\text { (US\$) }\end{array}$ & $\begin{array}{l}\text { Total } \\
\text { production } \\
\text { costs } \\
\text { (US\$) }\end{array}$ & $\begin{array}{l}\text { Seed } \\
\text { cotton } \\
\text { yield } \\
\left(\mathrm{kg} \mathrm{ha}^{-1}\right)\end{array}$ & $\begin{array}{l}\text { Cost per } \\
\text { kg (US\$) }\end{array}$ & $\begin{array}{l}\text { Income } \\
\text { from seed } \\
\text { cotton } \\
\left(\mathrm{US} \$ \mathrm{ha}^{-1}\right)\end{array}$ & $\begin{array}{l}\text { Net benefits } \\
\left(\mathrm{US} \$ \mathrm{ha}^{-1}\right)\end{array}$ & $\begin{array}{l}\text { Cost benefit } \\
\text { ratio }(\mathrm{CBR})\end{array}$ \\
\hline Control & 0 & 0 & 175.44 & 175.44 & 892 & 0.32 & 285.44 & 110 & 0.6 \\
\hline Amdoc EC & 0.3 & 12.25 & 175.44 & 187.69 & 1958 & 0.32 & 626.56 & 438.87 & 2.3 \\
\hline Nimbicidine & 1.25 & 9.65 & 175.44 & 185.09 & 1985 & 0.32 & 635.2 & 450.11 & 2.4 \\
\hline EngeoK247Sc & 0.75 & 8.77 & 175.44 & 184.21 & 1035 & 0.32 & 331.2 & 146.99 & 0.8 \\
\hline Talstar & 1.25 & 12.25 & 175.44 & 187.69 & 1966 & 0.32 & 629.12 & 441.43 & 2.3 \\
\hline Aster extreme & 0.3 & 19.65 & 175.44 & 195.09 & 1733 & 0.32 & 554.56 & 359.47 & 1.8 \\
\hline Agrolambacin & 1.2 & 18.25 & 175.44 & 193.69 & 1846 & 0.32 & 590.72 & 397.03 & 2.0 \\
\hline Larvin 80DF & 1 & 13.33 & 175.44 & 188.77 & 1567 & 0.32 & 501.44 & 312.67 & 1.6 \\
\hline Lannet 40SP & 1.25 & 17.54 & 175.44 & 192.98 & 1386 & 0.32 & 443.52 & 250.54 & 1.3 \\
\hline
\end{tabular}

Seed cotton costs per kg adopted from CDO Annual Report 2010, other production costs are compilation by the author from Serere cotton farmers, treatment costs are compilation by the author from pesticide dealers in Uganda, USD $\$$ rate adopted from Uganda forex bureau rates 2013 ( 1 USD $=2850$

UGX) 
Table 6. Estimates of cost benefit analysis of the new pesticides in the study at the National Semi Arid Resources Research Institute (NaSARRI) in Uganda

\begin{tabular}{|c|c|c|c|c|c|c|c|c|c|}
\hline Treatments & $\begin{array}{l}\text { Quantity } \\
\text { per ha }\end{array}$ & $\begin{array}{l}\text { Cost per } \\
\text { treatment } \\
\left(\mathrm{US} \$ \mathrm{ha}^{-1}\right)\end{array}$ & $\begin{array}{l}\text { Other } \\
\text { production } \\
\text { costs } \\
\text { (US\$) }\end{array}$ & $\begin{array}{l}\text { Total } \\
\text { production } \\
\text { costs } \\
\text { (US\$) }\end{array}$ & $\begin{array}{l}\text { Seed } \\
\text { cotton } \\
\text { yield } \\
\left(\mathrm{kg} \mathrm{ha}^{-1}\right)\end{array}$ & $\begin{array}{l}\text { Cost per } \\
\text { kg (US\$) }\end{array}$ & $\begin{array}{l}\text { Income } \\
\text { from seed } \\
\text { cotton } \\
\left(\mathrm{US} \$ \mathrm{ha}^{-1}\right)\end{array}$ & $\begin{array}{l}\text { Net benefits } \\
\left(\mathrm{US} \$ \mathrm{ha}^{-1}\right)\end{array}$ & $\begin{array}{l}\text { Cost benefit } \\
\text { ratio }(\mathrm{CBR})\end{array}$ \\
\hline Control & 0 & 0 & 175.44 & 175.44 & 602 & 0.53 & 319.06 & 143.62 & 0.8 \\
\hline Amdoc EC & 0.3 & 10.53 & 175.44 & 185.97 & 1506 & 0.53 & 798.18 & 612.21 & 3.3 \\
\hline Nimbicide & 1.25 & 9.65 & 175.44 & 185.09 & 1715 & 0.53 & 908.95 & 723.86 & 3.9 \\
\hline EngeoK247Sc & 0.75 & 8.77 & 175.44 & 184.21 & 1005 & 0.53 & 532.65 & 348.44 & 1.9 \\
\hline Talstar & 1.25 & 10.53 & 175.44 & 185.97 & 1935 & 0.53 & 1025.55 & 839.58 & 4.5 \\
\hline Aster extreme & 0.3 & 19.65 & 175.44 & 195.09 & 1930 & 0.53 & 1022.9 & 827.84 & 4.2 \\
\hline Agrolambacin & 1.2 & 18.25 & 175.44 & 193.69 & 1722 & 0.53 & 912.66 & 718.97 & 3.7 \\
\hline Larvin 80DF & 1 & 13.33 & 175.44 & 188.77 & 1360 & 0.53 & 720.8 & 532.03 & 2.8 \\
\hline Lannet 40SP & 1.25 & 17.54 & 175.44 & 192.98 & 1080 & 0.53 & 572.4 & 379.42 & 1.9 \\
\hline
\end{tabular}


than or equal to one compared to the untreated controls.

\section{Discussion}

Overall, Nimbicidine and Talstar were the most effective biopesticides against Helicoverpa amigera larvae (Table 1), followed three synthetic pesticides; Engeo, Amdoc, Aster Extreme and Agrolambacin. Larvin 80DF, Lannate 40SP were less effective compared to the biopesticides and other synthetic pesticides in the experiment but their results were significantly higher than the controls. The results of this study indicate that plantbased pesticides such as Nimbicidine and Talstar are effective alternatives to conventional synthetic pesticides for the control of Helicoverpa amigera and natural enemies' population conservation (Figs. 1 and 2, Table 2).

Similarly to the laboratory experiment in Table 1, Biopesticides treated plots were the most effective pesticides against the American bollworm larvae in the field compared to the synthetic pesticides. Although the synthetic pesticides performed significantly higher than the untreated controls (Fig. 1 and 2). Although our experiment and those of other authors used different doses against various instars and under different climatic conditions, our findings are in agreement with Gergis et al. (2003) who reported $79.3 \%$ reduction in bollworm populations after three consecutive sprays with biopesticides.

The present study, therefore, fully reflects the efficacy of the tested insecticides and offers cotton famers alternative options for control of bollworms in cotton cropping systems.

There was significant $(\mathrm{p}<0.001)$ reduction of the ladybird and Chysoperla Carnea populations in the current study irrespective of the type of insecticide/ pesticide applied (Table 2). The sensitivity of natural enemies to pesticides application could be the reason for their reduction after application of pesticides in this study. This is in agreement with Ngari et al. (2003) who found organophosphates to be highly toxic to the natural enemies especially the ladybird beetles. The highest seed cotton yield was obtained from biopesticides treated plots, followed by the synthetic pesticides treated plots with very low yields obtained in the untreated controls (Tables 3 and 4).

These results agree with observations elsewhere that the control inside may under estimate the efficacy of the pesticides (Ngari et al., 2007). The pest attack in such plot may differ from that which would occur on unsprayed cotton without adjacent sprayed cotton.

In this experiment biopesticide treated plots had significantly higher yield compared to the synthetic pesticides treated plots. This study also concurs with findings by Ngari et al ., 2007 who also obtained similar results. He also observed that yields of unsprayed control plots within sprayed trials may be greater, or less than the yields, which would have been obtained from larger plots of unsprayed cotton. This is probably because removal of the barrier after application, pesticides may diffuse to the inside control thus behaving as if chemicals have been applied. This study also suggests that natural enemies migrated to control plots hence causing significant impact on the pest populations.

Considering the $\mathrm{BCR}$ ratios for the new pesticides in this study the pesticides had highly significant financial viability ratios with biopesticides Nimbicidine and Talstar among the most viable options followed by Aster extreme, Agrolambacin, 
Amdoc EC, Larvin and finally Lannate as compared to the no control option which is financially not viable.

Therefore considering the economic facts attributed to these new synthetic pesticides farmers can use these new pesticides in rotation with the already existing synthetic pesticides in order to prevent the cotton bollworm from developing resistance from the already existing synthetic pesticides.

Ecologically, in order to maintain natural enemies diversity, cotton farmers should use the biopesticides which are ecofriendly with less effect on the natural enemies population thereby boosting ecosystems function.

This study recommends use of Nimbicidine, Talstar as commercially available biopesticides in rotation with the new synthetic pesticides including Aster extreme, Agrolambacin and Amdoc together with cultural management practices.

\section{Acknowledgement}

Financial support for this work was provided by the National Agriculture Research Organisation (NARO-ATAAS project) in collaboration with the Cotton Development Organisation (CDO) of Ministry of Agriculture, Animal Industry, and Fisheries of Uganda Government.

\section{References}

Abbott, W.S. 1925. A method of computing the effectiveness of an insecticide. Journal of Economic Entomology 18: 265-267.

Ahmad, M., Arif, M.I. and Attique, M.R.1997. Pyre-throid resistance of, Helicoverpa armigera "Hub." in
Pakistan. Bulletin of Entomology. Reserve 87: 343-347.

Asogwa et al,. 2011. Evaluation of Engeo K 247 SC for routine protection of cocoa farms against the brown Cocoa Mirid - Sahlbergella singularis in Nigeria

Busvine, J.R. 1971. A critical review of the techniques for testing of insecticides. $2^{\text {nd }}$ ed. London: Commonwealth Agricultural Bureaux, $345 \mathrm{p}$.

CABI. 2016. Fact sheets on Helicoverpa amigera. Crop Protection Compendium. Common wealth Agricultural Bureau, International. http://www.cabicompendium.org/.

Costelloe, B.E. 1968. Routine method of acid-delinting cotton seed for experimental purposes. Cotton Growing Review 45:219-222.

Cotton Development Organisation (CDO)-Cotton production, lint and fibre quality characteristics. Annual Report 2013.

Eugenia. 2015 Comparative cost-benefit analysis of using integrated crop management technology and conventional method in vegetable production in the lower Manya Krobo district of Ghana. PhD thesis, University of Ghana, Legon.

Gergis et al. 2003. Compatible IPM program of "Agrein and Trichoderma" in cotton.Beltwide cotton conference, washville.TN.USA:1425-1432

Guolei, F., Fengqin, H., Jiangui,Y., Jiling, L., Mei, L., Yunqin, S., Yue, H., Pengbin, Z. and Minqing, W. 1995. Monitoring and managing of the resistance to insecticide in cotton bollworm, Helicoverpa armigera "Hub.". Sinozool-gia, (12 suppl.), 80-85. 
Herve, J.J. 1985. Agricultural, public health and animal usage, pp 343-425. In: J. P. Leahey, the pyrethroids insecticides. Taylor and Francis, London.

Kranthi, R.K., Armes, N.J., Rao, N.G.V., Raj, S. and Sundraramorthy, V.T. 1997. Seasonal dynamics of metabolic mechanisms mediating pyrethroid resistance in Helicoverpa armigera "Hub." in Central India. Pesticide Science 50: 91-98.

Lohar, M.K. 1994. Insect pests of cotton. Applied Entomology (Chapter 12), pp.106, Dept. Entomology. Sindh Agric. Univ., Tandojam Sindh, Pakistan.

Munro, J.H. 1987. Cotton. Tropical Agricultural Series. Longman Group UK Limited. 436p.

Naveed Haider, Kanwer Shahzad Ahmed, Azhar Abbas Haidary,Muhammad Afzal, Muhammad Zeeshan Majeed, 2015. Field evaluation of different insecticides against spotted bollworm (Earias spp.) and comparative yield assessment for BT and non-Bt cotton. Journal of entomology and zoology studies

Ngari, B.M., Ngatia, T. and Njinj, S.M. 2007. Effects of deltaphos $212 \mathrm{ec}$ (triazophos 200g /deltamethrin 12ga.i. per litre) and thunder 145od (beta cyfluthrin $45 \mathrm{~g} /$ imidacloprid $100 \mathrm{~g}$ per litre) on sucking and chewing pests and their natural enemies of cotton in Kenya

Ngari, B.M. 2004. African bollworm: pest status, present knowledge and options for control in cotton pests in the cotton growing regions of Kenya. In: Sithanantham, S, Kariuki, C. and Baya J. (eds.): Helicoverpa Management in Kenya: Research status and needs. Proceedings of KARI-ICIPE
Workshop on Biocontrol-based IPM of the African bollworm in Kenya. pp. 8391. ICIPE Science Press, Nairobi xii$113 \mathrm{pp}$

Ngari, B.M., Waturu, C.N., Onzere, B.B., Nzeve, D.N and Kagito, S.K 2003. Evaluation of Bulldock Star 262.5 EC (Beta-cyfluthrin 12.5/Chloropyrifos $250 \mathrm{~g}$ a.i. per litre) against sucking and chewing insect of Cotton. In: KARIMwea Annual Report. pp. 49-55.

Reed, W. 1972. Uses and abuses of unsprayed controls in spraying trials. Cotton Growing Review 49:67-72.

Rogers, M.A. 2012. Efficacy of biopesticides for organic management of cucumber beetles "PhD diss., University of Tennessee, USA.

Sawicki, R.M. and Denholm, I. 1987. Management of resistance to insecticides in cotton pests. Tropical Pest Management 33: 262-272.

Surpam, A.N., Neharkar, P.S., Shubhangi, P., Bhasme, Kamdi, S.R. and Kadam B.S. 2015. Bio-efficacy of new combiproduct against cotton boll worms, Maharashtra state-India. Indian Journal of Plant Sciences

Syed Arif, Hussain Rizvi, Muhammad Nadim, Ikhlaq, Saleem Jaffar and Shahid Hussain 2015. Efficacy of some selected synthetic chemical insecticides and bio-pesticides against cotton mealybug, Phenacoccus solenopsis Tinsley (Sternorrhyncha: Pseudococcidae) under agro ecological conditions of Peshawar, Pakistan.

Uganda Bureau of statistics (UBOS) 2015. Statistical abstracts 2015. Statistics house, plot 9, Colville Street, Uganda.www.ubos.org

USA department of Agriculture 2016.92 ${ }^{\text {nd }}$ Annual Agricultural outlook forum transforming Agriculture. Annual 
budgets and performance V.W. 2002. Recommendations for outlook.www.performance.gov growing cotton in Kenya. Kenya Usman, A.A., Watson, T.F. and Agricultural Research Institute Sivasupramaniam, S. 1991. Reversion of Permethrin resistance in field stains and selection for Azinophosmethyl and Permethrin resistance in Pink Bollworm (Lepidoptera: Gelechiidae). Journal of Economic Entomology 84 (2): 353-357. Annual Report. 10pp.

Yongqiang, Li, Jianwei, Liu, Mei, Lu, Zhiqing, Ma, Chongling Cai, Yonghong Wang and Xing Zhang, 2016. Bacterial expression and kinetic analysis of Carboxylesterase 001D from Helicoverpa armigera. Waturu, CN., Opondo, R.M., Macharia, J.M.K., Onzere, B.B and Wasike, International Journal of Molecular Sciences 